\title{
Risk Prevention of Ventilator-Associated Pneumonia Thorough Oral Hygiene: A Literature Review
}

\author{
Musdalipah*, Yuliana Syam, Takdir Tahir \\ Master Program of Nursing, Faculty of Nursing, Universitas of Hasanuddin, Indonesia
}

\begin{abstract}
Ventilator-Associated Pneumonia (VAP) is a type of nosocomial infection that mostly occurs in intensive care units, generally occurring 48 hours after intubation. Endotracheal intubation and the use of a mechanical ventilator are invasive measures by patients, having a therapeutic effect. This paper aimed to identify the use of oral hygiene materials for the incidence of pneumonia related to the use of a ventilator. The research design was by searching literature in five databases, namely PubMed, Proquest, Science Direct, Wiley Online Library, and Google Scholar, by taking all databases in English and Indonesian, published in the last ten years (2010-2020). There were six articles about the effectiveness of using oral hygiene as risk prevention for Ventilator-Associated Pneumonia (VAP) with various concentrations and volumes. Several oral health assessment tools that can be used are Oral Assessment Guide, Beck Oral Assessment Scale, or Mucosal-Plaque Score. Comprehensive implementation of oral hygiene can improve the oral health of patients with mechanical ventilation, so bacterial colonization that causes VAP can be prevented. Therefore, nurses need to understand and apply oral assessment instruments as a basis for giving intervention.
\end{abstract}

Keywords: Intensive care unit, Oral hygiene, Ventilator-Associated Pneumonia

\section{INTRODUCTION}

The mortality and disability rates in critically ill patients who are admitted to the ICU were increasing from year to year. It is due to disease conditions, care, and nosocomial infections in the hospital. One of the most common nosocomial infections in the ICU is a complication of using a ventilator was Ventilator-Associated Pneumonia (VAP).

A ventilator is a breathing device to maintain optimal ventilation and maximize oxygen transport [1]. There have been many strategies that have been implemented to prevent the incidence of VAP. One of which is oral hygiene, the most important part of nursing interventions in intensive care. However, it is necessary to consider the negative effects that will be experienced by patients. Antibiotic resistance and risk of aspiration are some of the effects that can be fatal in patients [2], so it is necessary to find alternatives in oral care regimens.

Endotracheal intubation and the use of mechanical ventilators are invasive measures by patients who are treated in intensive care, but apart from having therapeutic effects, they can also cause side effects. It was VentilatorAssociated Pneumonia, increased morbidity rates around $24-70 \%$, and in the length of stay 9.6 days, thus significantly increasing the cost of care and treatment at the hospital [3].

${ }^{*}$ Correspondence address:

Musdalipah

Email : iffahullaina@gmail.com

Address : : Jl. Perintis Kemerdekaan No.KM.10, Tamalanrea Indah, Makassar, South Sulawesi 90245
The patient condition in the care unit received several invasive measures, and the treatment caused an immunosuppressive and was prone to antibiotic resistance. The installation of an endotracheal tube causing the oral condition to become worse. The continuous open oral causes the mucosa to become dry, saliva production decreases because the mechanical function of the mouth does not play a role after all food is inserted through a nasogastric tube.

Nurses play a crucial role in performing oral hygiene interventions as measure prevention of the risk of VAP. Previous studies have widely explained that oral health is closely related to the incidence of VAP, with an incidence of up to 117 per 1000 ventilator days with 69 patients (42.6\%) developing early-onset VAP at 0-48 hours of Endotracheal Tube (ETT) use [4].

The risk of VAP incidence can be prevented through maximum oral care by reducing bacterial and fungal overgrowth [5]. Good oral care will also significantly reduce plaque, salivary bacteria, and potential respiratory pathogenic cells [6], but the standards for oral hygiene in each hospital are different [7]. Interventions can be different according to the standard operating procedures of each hospital. Research revealed that chlorhexidine $0.12 \%$ is the golden standard of oral care because it has antibacterial and antiplaque effects [8].

This paper aimed to identify the effects of using oral hygiene materials on the incidence of pneumonia-related use of a ventilator as the primary outcome. The secondary outcome/point 
of review including patient characteristics, instruments used, duration of time, method, frequency, and types of bacteria isolated, so that we can recommend alternatives for nurses in a clinical service.

\section{MATERIAL AND METHOD}

This study is a literature review by taking articles from all countries in English in the last ten years (2010-2020). In searching for articles, several databases are used, including Pubmed, Proquest, Science Direct, Wiley, and Google scholar. A list of references taken manually in the last ten years (2010-2020).

Searching articles using the keywords "oral care", "oral hygiene", "oral health care", "critical patient", "intensive care unit", "ventilatorassociated pneumonia", and "VAP". If there is an inaccessible article, the author does not make any search efforts. Content analysis was not carried out if the samples were varied, the results and methods were different. For this literature review, the authors analyzed the data based on the similarity of oral hygiene interventions and their effects on oral health and colonization of types of oral bacteria.

\section{RESULT AND DISCUSSION}

The PubMed search results totaled 13 articles, ProQuest 14 articles, Science Direct 11 articles, Wiley 11 articles, Gray literature 15 articles, thus brought a total of 64 articles. The results were specified for publications in the last ten years (2010-2020) in English. Then the exclusion results, which is not a full text, nonexperimental, and multiple articles were 30 articles. There 28 articles that were not accordance to the resulting study, so that only six articles were included for the final review.

Table 1. Description of Article Review

\begin{tabular}{|c|c|c|c|}
\hline Objective & Respondents & Intervention & Results \\
\hline $\begin{array}{l}\text { Evaluate the efficacy and } \\
\text { safety of oral care with } \\
\text { povidone-iodine on the } \\
\text { occurrence of ventilator- } \\
\text { associated pneumonia in the } \\
\text { high-risk population [10]. }\end{array}$ & 119 & $\begin{array}{l}\text { Participants were randomly } \\
\text { assigned to received } \\
\text { oropharyngeal care with } \\
\text { povidone-iodine six times daily } \\
\text { until mechanical ventilation } \\
\text { withdrawal. }\end{array}$ & $\begin{array}{l}\text { There was a significant difference } \\
\text { between the groups for ventilator- } \\
\text { associated tracheobronchitis: the } \\
\text { povidone-iodine group and the } \\
\text { placebo group. }\end{array}$ \\
\hline $\begin{array}{l}\text { Comparing the effectiveness } \\
\text { of oral hygiene using } \\
\text { lactoperoxidase enzymes } \\
\text { with chlorhexidine in VAP } \\
\text { prevention [12]. }\end{array}$ & 127 & $\begin{array}{l}\text { Determined the group that to be } \\
\text { used as an experiment, which } \\
\text { using chlorhexidine and Oral } \\
\text { Hygiene. }\end{array}$ & $\begin{array}{l}\text { There was no significant difference } \\
\text { in oral hygiene using Lactoperoxide } \\
\text { and Chlorhexidine in the } \\
\text { prevention of ventilator-associated } \\
\text { pneumonia. }\end{array}$ \\
\hline $\begin{array}{l}\text { Effect of the implementation } \\
\text { of oral hygiene using } \\
\text { antiseptic hexanol gargle in } \\
\text { minimizing the incidence of } \\
\text { Ventilator-Associated } \\
\text { Pneumonia (VAP) in R. ICU, } \\
\text { Tugurejo Hospital [13]. }\end{array}$ & 15 & $\begin{array}{l}\text { The pre-test and the post-test } \\
\text { data were taken on the first day } \\
\text { and fifth day when the ventilator } \\
\text { was installed. They used the } \\
\text { same antibiotic and used SOP of } \\
\text { oral hygiene and clinical } \\
\text { pulmonary infection score (CPIS) } \\
\text { observation sheet. }\end{array}$ & $\begin{array}{l}\text { There was a significant difference } \\
\text { before and after oral hygiene using } \\
\text { hexanol gargle the incidence of } \\
\text { ventilator-associated pneumonia } \\
\text { (VAP). }\end{array}$ \\
\hline $\begin{array}{l}\text { Evaluate the effects of oral } \\
\text { hygiene with hexanol and } \\
\text { chlorhexidine in patients } \\
\text { with mechanical ventilators } \\
\text { in ICU [1]. }\end{array}$ & 30 & $\begin{array}{l}\text { The subjects were divided } \\
\text { randomly into two groups: } \\
\text { subjects given by hexanol } 0.1 \% \\
\text { and given by chlorhexidine } 0.2 \% \\
\text { twice a day. }\end{array}$ & $\begin{array}{l}\text { There was no significant difference } \\
\text { in oral hygiene with the use of } \\
\text { hexanol and chlorhexidine. }\end{array}$ \\
\hline
\end{tabular}




\section{Ventilator-Associated Penumonia (VAP)}

Ventilator-Associated Pneumonia (VAP) is a type of nosocomial infection that mostly occurs in intensive care units, usually occurring 48 hours after intubation. VAP defines as a condition of the presence of a new infiltrate and permanent on the chest X-ray accompanied by one of the signs in the form of a blood or pleural culture similar to microorganisms found in sputum or tracheal aspiration, cavitation on chest radiographs according to the American College of Chest Physician. There are three symptoms, i.e. high fever, leukocytosis, and a type of nosocomial infection that most often occurs in intensive care [14]. It generally occurs after 48-72 hours after the endotracheal tube (ETT) insertion to patients who use mechanical ventilator support. If this occurs after the first four days of mechanical ventilation, then this VAP is considered early-onset, whereas late-onset occurs after the 5th day of mechanical ventilation.

\section{Risk Factors}

Risk factors incidence of VAP in the ICU, including the history of disease/comorbidity patient, such as the history of lung disease, smoking, the history of diabetes mellitus, and the suction method [5]. Besides age, gender, trauma, and the influence of antibiotic use, VAP is also closely related to patient oral hygiene [15]. Although a diagnosis of VAP is difficult to be established, its incidence increased inpatient length of stay up to 9.6 days. The increase in care and treatment costs for each patient is US\$ 40,000 , which implies a high mortality rate of 24 $70 \%$ of patients in ICU [16].

\section{Pathogenesis of VAP}

Ventilator-Associated Pneumonia (VAP) occurs due to disruption of the body's defense system, especially in patients with decreased consciousness. The patient loses the ability to perform care and maintain oral hygiene. It causes mechanical functions of the mouth such as chewing, biting food, and swallowing have decreased. The natural defense system cannot function properly, causing the accumulation of bacteria in the oropharynx, bronchi, and trachea [17]. Saliva production has also decreased [18]. There is a buildup of plaque on teeth and biofilms on the tooth surface, which is beneficial for bacterial growth and colonization.

According to the Clinical Practice Guideline for Hospital-Acquired Pneumonia (HAP) and VAP in adults [19], this infection occurs when the patient is admitted to the ICU and uses mechanical ventilation for more than 48 hours, with an increased risk of incidence 3-10 times with a fairly high mortality rate between $24-50 \%$. It can reach $76 \%$ under certain conditions when compared to patients who are not on a ventilator.

\section{Caused of VAP}

Some bacteria as the cause of VAP are generally gram-negative bacteria, including; Pseudomonas, Klebsiella pneumonia, Enterobacter, Serratia spp, and Acinetobacter spp. The diagnosis of VAP is established using the CPIS assessment instrument, includes purulent bronchial secretions, leucopenia $<1000 . \mathrm{mm}^{-3}$ or leucocytosis $>12,000 \cdot \mathrm{mm}^{-3}$, increased body temperature $>38^{\circ} \mathrm{C}$ or $<36^{\circ} \mathrm{C}$ without cause, positive blood culture, and visible infiltrates on chest $x$-ray. If three of these symptoms occurred in an intubated patient, a VAP can be diagnosed [14].

\section{Prevention of VAP}

Among the VAP prevention strategies, oral care is the most crucial part for nurses in the ICU to maintain oral health and prevent the colonization of pathogenic bacteria that cause pneumonia. It stated in a study that there is a strong correlation between unhealthy oral conditions and an increased incidence of VAP [20].

\section{Oral Hygiene}

Oral hygiene is the act of cleaning the oral cavity, teeth, and tongue. This action is one of the essential interventions in intensive care, which affects patient care and recovery [20]. Prioritizing oral hygiene for patients in critical care can prevent complications that will aggravate the patient's condition. It is very important to maintain the integrity of the lips, tongue, and oral mucosa. Thus, routine oral hygiene can prevent infection of the oral cavity and moisturize mucous membranes of the mouth and lips.

\section{Impact of Oral Hygiene}

Some of the oral hygiene that is not optimal causes periodontal infections to occur, trauma to the gums, moldy/white tongue, stomatitis, gingivitis, discoloration of teeth, and caries. In critical patients, the natural defense function is impaired, making it easier for infection to occur in the respiratory tract. If no action is taken in prevention, it causes increased bacterial colonization, and bacteria can translocate to the 
(Musdalipah, et al.)

lower respiratory tract, which triggers pneumonia (ventilator-associated pneumonia).

Several ingredients are often used for oral hygiene, including normal saline, chlorhexidine, povidone-iodine, toothbrush and toothpaste, as well as honey. Some studies explained that added chlorhexidine to oral care will reduce infection-causing bacteria, as well as a broadspectrum antibacterial, which will reduce the incidence of ventilator-associated pneumonia [21]. Some side effects of chlorhexidine have been reported, like dry oral mucosa, tooth staining, taste changes, and the long-term effect is resistance to certain bacteria [22].

\section{CONCLUSION}

The main intervention for the prevention of oral infections in patients on mechanical ventilators is oral hygiene. The mouth is the main gateway for bacteria that cause infection. Therefore, oral hygiene needs to be considered comprehensively by nurses who are in charge of intensive care. The frequency of implementation of oral hygiene is adjusted to the results of the oral health assessment of each patient. All of these components are intended to prevent the colonization of microorganisms, so the incidence of VAP in patients in intensive care rooms with mechanical ventilation can decrease.

\section{References}

[1] Atmaja, H.K. 2018. Komparasi pemberian hexadol dan chlorhexidine sebagai oral hygiene terhadap pencegahan Ventilator Associated Pneumonia (VAP). Jurnal Kesehatan Prima. 8(1). 1185-1191.

[2] Jackson, L., M. Owens. 2019. Does oral care with chlorhexidine reduce ventilatorassociated pneumonia in mechanically ventilated adults? Br. J. Nurs. 28(11). 682689. DOI: 10.12968/bjon.2019.28.11.682.

[3] Burns, J. 2011. An evidenc-based guide to planning care, $10^{\text {th }}$ Ed. Elsevier.

[4] Saensom, D., A.T. Merchant, W. Ruaisungnoen, W. Pitiphat. 2016. Oral health and ventilator-associated pneumonia among critically ill patients: a prospective study. 709-714. DOI: 10.1111/odi.12535.

[5] Messika, J., B. La Combe, J.D. Ricard. 2018. Oropharyngeal colonization: epidemiology, treatment and ventilator-associated pneumonia prevention. Ann. Transl. Med. 6(20). 426-426. DOI: 10.21037/atm.2018. 10.17 .

[6] Abhary, M., A.A. Al-Hazmi. 2016.
Antibacterial activity of Miswak (Salvadora persica L.) extracts on oral hygiene. J. Taibah Univ. Sci. 10(4). 513-520. DOI: 10.1016/ j.jtusci.2015.09.007

[7] Atay, S., Ü. Karabacak. 2014. Oral care in patients on mechanical ventilation in intensive care unit: a literature review. Int. J. Res. Med. Sci. 2(3). 822-829.

[8] Bhaskar, D.J., R.K. Gupta, 2015. Evaluasi komparatif madu, chlorhexidine glukonat (0.2\%) dan kombinasi xylitol dan tingkat klinis plak gigi : uji coba acak selama 30 hari. 6. 53-58. DOI: 10.4103/2229-3485.148819.

[9] Nicolasi, L.N., M. del Carmen-Rubio, C.D. Martinez, N.N. González, M.E. Cruz. 2014. Effect of oral hygiene and $0.12 \%$ chlorhexidine gluconate oral rinse in preventing ventilator-associated pneumonia after cardiovascular surgery. Respir. Care. 59(4). 504-509. DOI: 10.4187/respcare. 02666.

[10] Seguin, P., B. Laviolle, C. Dahyot-Fizelier, R. Dumont, B. Veber, S. Gergaud, et al. 2014. Effect of oropharyngeal povidone-iodine preventive oral care on ventilator-associated pneumonia in severely brain-injured or cerebral hemorrhage patients: a multicenter, randomized controlled trial. Crit. Care Med. 42(1). 1-8.

[11] Lestari, M.I. 2017. Hubungan antara klorheksidin 0, 2\% dan Povidone lodine 1\% dengan Ventilator-Associated Pneumonia (VAP): studi kohort. Majalah Anestesia dan Critical Care. 35(1). 19-26.

[12] Purnama A., R. Fikri. 2020. Perbandingan efektifitas oral hygiene menggunakan enzym lactoperoxidase dengan chlorhexidine dalam pencegahan VAP di ICU RS X. Jurnal Surya Muda. 2(1). 54-64.

[13] Tohirin, A., M. Saparwati, S. Haryani. 2019. Pengaruh oral hygiene menggunakan hexadol gargle dalam meminimalkan kejadian Ventilator Associated Pneumonia (VAP) di ruang ICU RSUD Tugurejo Semarang. Jurnal Keperawatan dan Kesehatan Masyarakat Cendekia Utama. 8(1). 9-16.

[14] International Nosocomial Infection Control Consortium, Rosenthal, V.D. 2016. International Nosocomial Infection Control Consortium (INICC) resources: INICC multidimensional approach and INICC surveillance online system. Am. J. Infect. Control. 44(6). e81-e90. DOI: 10.1016/j.ajic. 2016.01.005.

[15] Alecrim, R.X., M. Taminato, A. Belasco, 
M.C.B. Longo, D.M. Kusahara, D. Fram. 2019. Strategies for preventing ventilatorassociated pneumonia: an integrative review. Rev. Bras. Enferm. 72(2). 521-530. DOI: 10.1590/0034-7167-2018-0473.

[16] Koenig, S.M., J.D. Truwit. 2006. Ventilatorassociated pneumonia: Diagnosis, treatment, and prevention. Clin. Microbiol. Rev. 19(4). 637-657. DOI: 10.1128/CMR.00051-05.

[17] Juneja, D., O. Singh, Y. Javeri, V. Arora, R. Dang, A. Kaushal. 2011. Prevention and management of ventilator-associated pneumonia: A survey on current practices by intensivists practicing in the Indian subcontinent. Indian J. Anaesth. 55(2). 122128. DOI: 10.4103/0019-5049.79889.

[18] Ramsay, E. I., S. Rao, L. Madathil, S.K. Hegde, M.P. Baliga-Rao, T. George, M.S. Baliga. 2019. Honey in oral health and care: A minireview. J. Oral Biosci. 61(1). 32-36. DOI: 10.1016/j.job.2018.12.003.

[19] Rotstein, C., G. Evans, A. Born, R. Grossman, R.B. Light, S. Magder, B. McTaggart, K. Weiss, G.G. Zhanel. 2008. Clinical practice guidelines for hospital-acquired pneumonia and ventilator-associated pneumonia in adults. Can. J. Infect. Dis. Med. Microbiol. 19(1). 19-53. DOI: 10.1155/2008/593289.

[20] Andersson, M., B. Wilde-larsson, M. Persenius. 2018. Intensive care nurses fail to translate knowledge and skills into practice A mixed-methods study on perceptions of oral care. Intensive Crit. Care Nurs. 52. 51-60. DOI: 10.1016/j.iccn.2018.09.006.

[21] Andini, A. 2012. Oral Hygiene terhadap jumlah bakteri orofaring pada penderita dengan ventilator. Medical Faculty, Diponegoro University. Semarang.

[22] Conley, P., D. McKinsey, J. Graff, A.R. Ramsey. 2013. Does an oral care protocol reduce VAP in patients with a tracheostomy? Nursing. 43(7). 18-23. DOI: 10.1097/01. NURSE.0000428709.81378.7c. 